mention. The book concludes with a superficial appraisal of the Yugoslav economic system (in terms of the rates of growth of output, unemployment, and inflation). The author does not attempt systematically to relate these economic data to the institutional changes described in previous chapters.

The book may prove useful to those readers who wish a description of the many institutional changes in the Yugoslav economy up to 1968. It has its limitations, however, as an overall analytic study and appraisal.

LAWRENCE J. BRAinard

Purdue University

\title{
SAMOUPRAVLJANJE I DRUSTVENA MOC: PRILOZI ZA SOCIOLOGIJU SAMOUPRAVNE RADNE ORGANIZACIJE. By Josip Županov. Zagreb: Naše teme, 1969. 332 pp.
}

The book contains twelve essays, most of which were published in periodicals during 1966-69. The twelve chapters are organized under five rubrics, each with a short introduction: workers' willingness to accept responsibility for the enterprise, theory of self-management, power of particular organizations in the enterprise, the role of the director, and the egalitarian value in Yugoslav enterprises.

The first section reveals that most employees in the ten enterprises studied were unwilling to accept responsibility for the enterprise; they favored running the enterprise even if it would be unprofitable. Only more educated persons, mostly in managerial positions, or members of the Communist League would stop inefficient enterprises. Županov reviews Taylor and authors of the human-relations school and says that their findings should be used in Yugoslav self-management, but suggests that their points are of lesser importance. He stresses that collective bargaining is essentially an antagonistic relationship and that in Yugoslavia there is a need for a participative relationship. Data were collected from attendants of labor schools by means of questionnaires. Most of the respondents favored increasing the power of directors. Generally it was felt that the director's job entails more difficulties than advantages. Respondents were undecided, however, whether the director's managerial function or his sociopolitical function was more important. Żupanov presents the responses of sixty directors, who stressed lack of time to manage all problems, even though the majority of directors said they devoted between nine to twelve hours a day to the enterprise. Most of the respondents also felt that specialists are not attracted to directors' jobs.

The problem of equality is discussed in the last section of the book. Variables such as education, length of service, and status in the factory are examined in relation to the value of equality. In this interesting analysis it was found that there was no relation to any of these sociological factors. Zupanov concludes that the value of equality is represented in all groups and social categories, as far as he could check analytically.

The Yugoslav self-government system appears to the author to be either moving toward a stage that could be characterized as "postbureaucratic" or toward a cultural adjustment which might nonrationally select for adoption certain behavioral norms. As a matter of fact, he is afraid that the latter is more likely to happen. It appears to him that the "unselective drifting character of the adjustment is somewhat of a cultural regression, because the traditional culture selects certain 
outward features of self-management (phraseology, exterior forms) and adapts them to its own patterns of action, norms, premises and values" (p. 317).

For the most part Županov's book is empirically oriented and does not hesitate to report difficulties and to reflect critically on the purpose of the self-government principle. By way of analogy, as English economists in the nineteenth century made certain free-market assumptions that were later found not quite to the point, Zupanov stresses certain differences between the normative order of self-management and its realization in practice. Županov collaborated with and was influenced especially by A. S. Tannenbaum of Michigan, and to some degree by Albert Meister of France. Unfortunately he fails to refer to some other empirical investigations of the Yugoslav workers' council. Since this book is a collection of studies published in different years, a general introduction serving to integrate them would be a help to the reader.

JrRI KoLAJA

West Virginia University

THE TURKISH STRAITS AND NATO. By Ferenc A. Vali. Hoover Institution Studies, 32. Stanford: Hoover Institution Press, 1972. xiii, 348 pp. $\$ 9.50$, cloth. $\$ 6.95$, paper.

In recent times the sine qua non of Western policy in the eastern Mediterranean has been the preservation of the status quo in the Turkish Straits. The Soviet Union's emergence in the $1960 \mathrm{~s}$ as a true Mediterranean seapower is a challenge in waters long accustomed to rules specified by powers other than Russia. Perhaps the most significant of the written rules are those which govern the Turkish Straits. In this book Professor Váli clearly shows the importance of the legal factors regarding the Straits, particularly those resulting from the Montreux Convention, and he does so with due regard for political, diplomatic, and psychological implications.

Even the most cursory student of East European history can see that Russian and Western misreadings-and the absence of readings-concerning events in waters associated with the Straits have had tragic international consequences in the past. This book shows that it is essential not to ignore or glide lightly over the potential dangers inherent in these waters. Turkey's dilemma demands that Western thinking avoid any tendency to shift attention from the Straits, to fail to associate the term "developing nations" with Balkan lands, or to consider that the outcome of the Soviet experiment with Mahan's doctrine rests primarily on events in other corners of the Mediterranean and in other waterways of the world. There is an urgent need for immediate consideration of actions such as those recommended by Váli.

The book re-emphasizes the point that with the Mediterranean as the major sea artery in the confrontation of Soviet and NATO naval forces, Turkey and the Turkish Straits can never be merely in the background. As Vali concludes, "the West also clearly has to recognize that Turkey's independence, her welfare, and her control over the Straits are essential to the security of the West and to international peace and stability." 